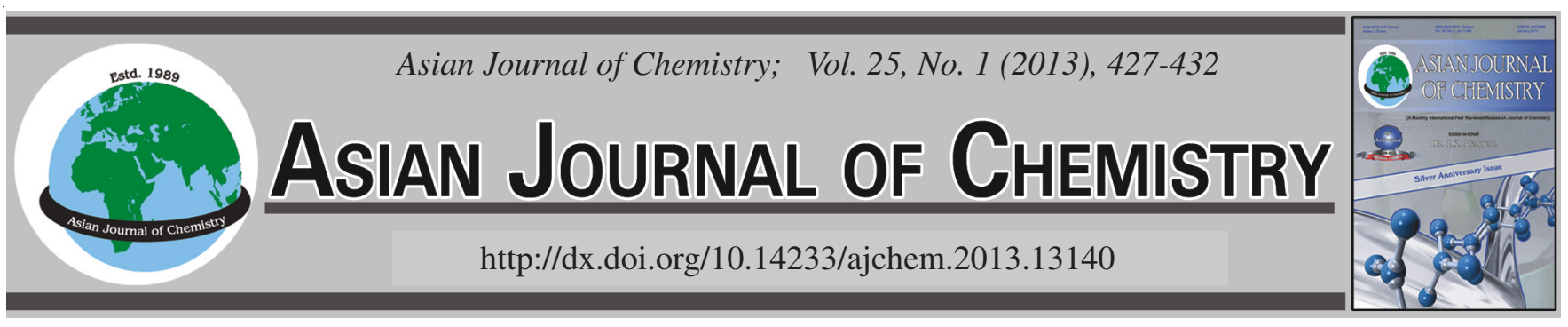

\title{
Role of Different Cytokinins and Auxins for Micropropagation, Callogenesis and Plant Regeneration in Lilium (Lilium longiflorum)
}

Aamir Ali*, Saira Yasmin, Rabia Shaheen Niazi, Abdul Majid and Naima Huma Naveed

Department of Biological Sciences, University of Sargodha, Sargodha, Pakistan

*Corresponding author: E-mail: aamirali73@hotmail.com

(Received: 29 November 2011;

\begin{abstract}
In vitro propagation of Lilium longiflorum was carried out to explore its potential for micropropagation and callogenesis using meristem and twin scales explants and to study the influence of different concentrations and combinations of various phytoharmones along with varying physical factors like temperature and light. MS medium supplemented with $2 \mathrm{mg} / \mathrm{L}$ of BAP was found to be best for shoot formation from meristem, with $84 \%$ shoot formation within 12 days of meristem inoculation while in case of twin scales, $88 \%$ shoot initiation response was obtained on MS medium containing $1.5 \mathrm{mg} / \mathrm{L}$ of BAP with $0.5 \mathrm{mg} / \mathrm{L}$ of NAA after 12 days of inoculation. Maximum shoot multiplication response was obtained at $3 \mathrm{mg} / \mathrm{L}$ of Kinetin with an average of 4.8 shoots per culture vial after 8.2 days of inoculation. The best in vitro rooting response was obtained on MS medium supplemented with $1.5 \mathrm{mg} / \mathrm{L}$ of NAA i.e. an average of 5.2 roots were formed after 12 days of inoculation with an average root length of $1.76 \mathrm{~cm}$. When well developed in vitro plants were shifted for hardening on different media (sand, silt, peat, sand+ peat and sand+ silt+ peat in the ratio of 1:1, 1:1:1 respectively). $100 \%$ Hardening response was recorded on Peat. Maximum callus induction response (88\%) was obtained from twin scale explant after 9.8 days of inoculation on MS supplemented with $2.0 \mathrm{mg} / \mathrm{L}$ of NAA $+0.25 \mathrm{mg} / \mathrm{L}$ of BAP. A temperature of $26^{\circ} \mathrm{C}$ and photoperiod of $16 \mathrm{~h} / 8 \mathrm{~h}$ light/ dark in every $24 \mathrm{~h}$ cycle showed best response for in vitro culturing of Lilium.
\end{abstract}

Key Words: Cytokinins, Auxins, Micropropagation, Callogenesis, Lilium.

\section{INTRODUCTION}

Lilium is a leading cut flower ${ }^{1}$, which ranks seventh among the cut flowers industry in the world in terms of auction turnover and is a very popular pot plant as well. Lilium, tulip and freesia are the three most important bulbous crops in the commercial market, representing $24 \%$ of total flower production ${ }^{2}$.

The Easter lily (Lilium longiflorum) is a rich source of steroidal glycosides, a group of compounds that is responsible for some of traditional medicinal uses of lily. Purified steroidal glycosides were evaluated for growth inhibition activity against the plant pathogenic fungus, Botrytis cinerea. All of the compounds show weak growth inhibition activity against fungus, however, the natural acetylation of C-6"' of the terminal glucose in the acetylated steroidal glycoalkaloid, increased the antifungal activity by inhibiting the rate of metabolism of the compound by the fungus ${ }^{3}$. The bulbs of some species of Lilium including L. tigrinum and L. auratum are included in routine diet of Chinese and Japanese.

Lilies can be propagated both by vegetative and sexual methods. To maintain genetic purity most of the commercially grown cultivars are propagated through vegetative means by way of above ground bulbils and under ground bulb scales ${ }^{4,5}$, through bulb division, stem bulblets and stem bulbils. Seed being very small in size have slow rate of germination and seed propagation also results in variability ${ }^{6}$. Lilium is also attacked by several fungal (Botrytis, Basal rot, Blue mold, etc.) and viral diseases. In vegetative method of propagation plant once infected by pathogen can transfer it generation after generation. These all can cause extensive damage to the plants and bulbs. Therefore there is a dire need to introduce a rapid and reliable method for large scale production of disease free, high yielding, true to type planting material throughout the year at affordable prices.

Plant tissue culture in this context plays an important role especially to remove the problem of disease and rapid propagation. Plants raised through this method are disease free, true to type having high yield potential. In recent years, propagation of numerous ornamental plants by tissue culture has become an accepted commercial practice. Current production techniques for in vitro propagation of plants have allowed for strong and continued growth within the micropropagation industry. The present investigation describes role of cytokinins and auxins for micropropagation and callogenesis of Lilium longiflorum. 
TABLE-1

EFFECT OF DIFFERENT CONCENTRATIONS OF 6-BENZYLAMINO PURINE (BAP), KINETIN, BAP WITH KINETIN AND BAP WITH $\alpha, \alpha$-NAPHTHALENE ACETIC ACID (NAA) ON IN VITRO SHOOT FORMATION AND INITIATION

\begin{tabular}{|c|c|c|c|c|c|c|c|c|}
\hline \multirow[t]{2}{*}{ Media } & \multirow[t]{2}{*}{$\begin{array}{l}\text { Composition } \\
(\mathrm{mg} / \mathrm{L})\end{array}$} & \multirow[t]{2}{*}{$\begin{array}{l}\text { No. of } \\
\text { test tubes } \\
\text { cultured }\end{array}$} & $\begin{array}{l}\text { Days for } \\
\text { shoot } \\
\text { formation }\end{array}$ & $\begin{array}{l}\text { Average shoot } \\
\text { length } \\
\text { (cm) }\end{array}$ & $\begin{array}{l}\text { Rate of shoot } \\
\text { formation } \\
(\%)\end{array}$ & $\begin{array}{l}\text { Days for } \\
\text { shoot } \\
\text { initiation }\end{array}$ & $\begin{array}{l}\text { Average shoot } \\
\text { length } \\
\text { (cm) }\end{array}$ & $\begin{array}{l}\text { Rate of shoot } \\
\text { initiation } \\
(\%)\end{array}$ \\
\hline & & & \multicolumn{3}{|c|}{ Meristem } & \multicolumn{3}{|c|}{ Twin scales } \\
\hline MS basal & & 5 & $21 \pm 1.67^{\mathrm{ijk}}$ & $0.76 \pm 0.20^{\mathrm{fg}}$ & 24 & $27.2 \pm 0.74^{1}$ & $0.8 \pm 0.74^{\mathrm{k}}$ & 12 \\
\hline \multirow{9}{*}{$\begin{array}{l}\mathrm{MS}+ \\
\mathrm{BAP}\end{array}$} & 1.0 & 5 & $14.2 \pm 0.74^{\text {bcde }}$ & $1.59 \pm 0.37^{\text {cdefg }}$ & 32 & $22 \pm 0.89^{\mathrm{jkl}}$ & $0.68 \pm 0.21^{\mathrm{k}}$ & 16 \\
\hline & 1.5 & 5 & $13.8 \pm 0.4^{\text {bcde }}$ & $2.02 \pm 0.51^{\mathrm{abcde}}$ & 68 & $21 \pm 1.67^{\mathrm{jk}}$ & $1.32 \pm 0.31^{\mathrm{hijk}}$ & 36 \\
\hline & 2.0 & 5 & $12.2 \pm 0.74^{\text {bcde }}$ & $3.04 \pm \mathbf{0 . 8 3}^{\mathrm{a}}$ & 84 & $20.2 \pm 0.97^{\mathrm{j}}$ & $1.96 \pm 0.32^{\text {fghi }}$ & 80 \\
\hline & 2.5 & 5 & $15.4 \pm 0.8^{\operatorname{defg}}$ & $2 \pm 0.70^{\text {abcde }}$ & 48 & $19 \pm 0.89^{j}$ & $2.0 \pm 0.2^{\text {efghi }}$ & 56 \\
\hline & 3.0 & 5 & $17.6 \pm 0.8^{\text {ghij }}$ & $1.82 \pm 0.27^{\text {bcdef }}$ & 40 & $17.6 \pm 0.8^{\mathrm{hi}}$ & $2.14 \pm 0.36^{\mathrm{efgh}}$ & 60 \\
\hline & 3.5 & 5 & $19 \pm 0.89^{\text {hij }}$ & $1.76 \pm 0.70^{\text {bcdef }}$ & 32 & $18.8 \pm 0.74^{\mathrm{ij}}$ & $2.28 \pm 0.41^{\text {cdef }}$ & 32 \\
\hline & 4.0 & 5 & $21.8 \pm 0.74^{\mathrm{ijk}}$ & $1.66 \pm 0.74^{\text {cdefg }}$ & 36 & $17.4 \pm 0.8^{\mathrm{hi}}$ & $3.04 \pm .58^{\mathrm{abc}}$ & 76 \\
\hline & 4.5 & 5 & $22 \pm 0.63^{\mathrm{jk}}$ & $1.62 \pm 0.85^{\operatorname{cdefg}}$ & 36 & $15.6 \pm 1.01^{\mathrm{gh}}$ & $3.4 \pm 0.37^{\mathrm{ab}}$ & 80 \\
\hline & 5.0 & 5 & $23 \pm 1.09^{k}$ & $0.76 \pm 0.20^{\mathrm{fg}}$ & 20 & $20.2 \pm 0.97^{j^{\mathrm{k}}}$ & $3.1 \pm 0.28^{\mathrm{ab}}$ & 64 \\
\hline \multirow{6}{*}{ MS + Kin } & 1.0 & 5 & $16 \pm 1.41^{\text {efgh }}$ & $1.10 \pm 0.7^{\mathrm{efg}}$ & 40 & $17.6 \pm 0.8^{\mathrm{ij}}$ & $0.62 \pm 0.2^{\mathrm{kl}}$ & 32 \\
\hline & 1.5 & 5 & $12.2 \pm 0.74^{\text {abcd }}$ & $2.3 \pm 0.50^{\mathrm{abcd}}$ & 68 & $16 \pm 1.41^{\mathrm{gh}}$ & $1.12 \pm 0.3^{\mathrm{ijk}}$ & 36 \\
\hline & 2.0 & 5 & $14.6 \pm 1.62^{\operatorname{defg}}$ & $2.0 \pm 0.63^{\mathrm{abcde}}$ & 44 & $15 \pm 1.41^{\mathrm{fgh}}$ & $1.2 \pm 0.4^{\mathrm{ijk}}$ & 56 \\
\hline & 2.5 & 5 & $17.6 \pm 0.8^{\text {ghij }}$ & $1.8 \pm 0.74^{\text {bcdef }}$ & 40 & $14.6 \pm 1.62^{\mathrm{efg}}$ & $2.3 \pm 0.50^{\text {bcdef }}$ & 68 \\
\hline & 3.0 & 5 & $18.8 \pm 1.72^{\text {ghij }}$ & $1.60 \pm 0.8^{\text {cdefg }}$ & 36 & $12.6 \pm 1.8^{\mathrm{d}}$ & $3 \pm 0.31^{\text {abcd }}$ & 80 \\
\hline & 3.5 & 5 & $19.6 \pm 1.0^{1 \mathrm{ijk}}$ & $1.3 \pm 0.74^{\mathrm{defg}}$ & 32 & $13.8 \pm 0.4^{\mathrm{de}}$ & $1.38 \pm 0.74^{\text {ghijk }}$ & 44 \\
\hline \multirow{4}{*}{$\begin{array}{c}\mathrm{MS}+ \\
\mathrm{BAP}+ \\
\mathrm{Kin}\end{array}$} & $0.5+0.5$ & 5 & $18.8 \pm 1.72^{\text {ghij }}$ & $2 \pm 0.63^{\text {abcde }}$ & 40 & $17.6 \pm 0.8^{\mathrm{hi}}$ & $1.1 \pm 0.74^{\mathrm{jk}}$ & 56 \\
\hline & $1.0+0.5$ & 5 & $16 \pm 1.41^{\text {efgh }}$ & $2.6 \pm 1.01^{\mathrm{abc}}$ & 60 & $15 \pm 1.41^{\mathrm{efg}}$ & $2.2 \pm 0.74^{\operatorname{defg}}$ & 68 \\
\hline & $1.5+0.5$ & 5 & $13.8 \pm 1.46^{\text {bcde }}$ & $2.8 \pm 0.74^{\mathrm{ab}}$ & 80 & $12.2 \pm 0.74^{b}$ & $3 \pm 0.31^{\text {abcd }}$ & 88 \\
\hline & $2.0+0.5$ & 5 & $14.6 \pm 1.62^{\mathrm{defg}}$ & $2.3 \pm 0.50^{\mathrm{abcd}}$ & 68 & $14.6 \pm 1.6^{\mathrm{efg}}$ & $2.8 \pm 0.74^{\text {abcde }}$ & 70 \\
\hline \multirow{6}{*}{$\begin{array}{c}\mathrm{MS}+ \\
\mathrm{BAP}+ \\
\mathrm{NAA}\end{array}$} & $0.5+0.5$ & 5 & $20.2 \pm 0.97^{\mathrm{ijk}}$ & $0.63 \pm 0.15^{g}$ & 32 & $21 \pm 1.67^{\mathrm{jk}}$ & $0.96 \pm 0.42^{\mathrm{jk}}$ & 36 \\
\hline & $1.0+0.5$ & 5 & $18.4 \pm 1.01^{\text {ghij }}$ & $1.1 \pm 0.74^{\mathrm{efg}}$ & 40 & $20.2 \pm 0.97^{j}$ & $1.68 \pm 0.25^{\text {ghij }}$ & 40 \\
\hline & $1.5+0.5$ & 5 & $15.8 \pm 0.74^{\text {defg }}$ & $2.08 \pm 0.38^{\text {abcde }}$ & 60 & $17.4 \pm 0.8^{\mathrm{hi}}$ & $1.76 \pm 0.89^{\text {fghij }}$ & 56 \\
\hline & $2.0+0.5$ & 5 & $9.6 \pm 1.01^{\mathrm{a}}$ & $3.02 \pm 0.59^{a}$ & 84 & $12 \pm 0.89^{\mathrm{a}}$ & $3.44 \pm 0.89^{\mathrm{a}}$ & 88 \\
\hline & $2.5+0.5$ & 5 & $12 \pm 0.89^{\mathrm{abc}}$ & $1.22 \pm 0.48^{\text {defg }}$ & 52 & $14.6 \pm 1.62^{\mathrm{ef}}$ & $2.12 \pm 0.71^{\text {efgh }}$ & 70 \\
\hline & LSD 0.05 & & 3.04 & 0.88 & - & 1.97 & 0.72 & - \\
\hline
\end{tabular}

\section{EXPERIMENTAL}

For present study explants of Lilium were obtained from green houses of Agri Biotech Research Farms, Lahore, Pakistan. The undesired leaves, root segments and upper dry bulb scales were removed with the help of sterilized forceps. As meristematic portion and inner scales of Lilium has covering of rolled scales, therefore, these explants are naturally sterilized and it is not necessary to adopt an elaborate protocol for disinfection. However, to prevent any contamination from outer covering of scales, surface sterilization was carried out. For this purpose explant was first washed with running tap water. After drying thoroughly they were rinsed three times with autoclaved distilled water. The explants were then treated with $1 \%$ sodium hypochlorite solution for $15 \mathrm{~min}$ and then washed three times with sterilized distilled water to remove all the traces of sodium hypochlorite. This was followed by sterilization of explants in laminar air flow cabinet with $70 \%$ ethanol for $15 \mathrm{~min}$. After sterilization both meristem and twin scales $(0.5-1.0 \mathrm{~cm}$ in length) were used for inoculation in prescribed medium.

Both solid and liquid MS medium ${ }^{7}$ supplemented with different concentrations of auxins and cytokinins either alone or in combination with each other were used. The $\mathrm{pH}$ of the medium was adjusted between 5.7-5.8 with $0.1 \mathrm{~N}$ solution of $\mathrm{NaOH}$ or $\mathrm{HCl}$ and $0.6 \%$ agar was used for solidification of medium. The medium was autoclaved at $121{ }^{\circ} \mathrm{C}$ and $15 \mathrm{Ibs} /$ $\mathrm{Inch}^{2}$ pressure for $20 \mathrm{~min}$. In case of liquid medium autoclaved cotton was used to support the plant tissues. Cultures were maintained under fluorescent light having 2500 lux intensity. Incubation temperature conditions ranging from $23-27^{\circ} \mathrm{C}$ were tested and photoperiod of $16 \mathrm{~h}$ light and $8 \mathrm{~h}$ dark was maintained in every $24 \mathrm{~h}$ cycle. Sub-culturing was done after 5 weeks. During each sub-culturing all dead or dis-coloured shoots were removed. The data was recorded for days to shoot formation, number of shoot per culture vial, days for shoot multiplication, days for root induction and number of roots per plant. For hardening well developed in vitro plants were shifted into pots containing different media (sand, silt, peat, sand + peat and sand + silt + peat in the ratio of 1:1, 1:1:1 respectively). Potted plants were brought out from green house into open sun light after three week of hardening and eventually these plants were shifted into the field for further growth.

The experimental design was completely randomized with five replicate cultures for each hormonal treatment and each experiment was repeated thrice. Analysis of variance (ANOVA) depicting significance among means was calculated by Duncan's new multiple range test ${ }^{8}$.

\section{RESULTS AND DISCUSSION}

In vitro shoot formation/initiation: For shoot formation MS medium (Murashige and Skoog's medium) was supplemented with BAP and Kinetin either alone or in combination with each other. It was observed that shoot formation was obtained in almost all the media supplemented with BAP. However, it is evident from Table-1, that best shoot formation response (84\%) from meristem was obtained at $2.0 \mathrm{mg} / \mathrm{L}$ of 


\begin{tabular}{|c|c|c|c|c|c|}
\hline \multicolumn{6}{|c|}{$\begin{array}{l}\text { TABLE-2 } \\
\text { EFFECT OF DIFFERENT CONCENTRATIONS AND COMBINATIONS OF CYTOKININS } \\
\text { AND AUXINS ON in vitro SHOOT MULTIPLICATION }\end{array}$} \\
\hline Media & $\begin{array}{c}\text { Composition } \\
(\mathrm{mg} / \mathrm{L})\end{array}$ & $\begin{array}{l}\text { No. of test tubes } \\
\text { cultured }\end{array}$ & $\begin{array}{l}\text { Days for shoot } \\
\text { multiplication }\end{array}$ & $\begin{array}{l}\text { No. of shoots per } \\
\text { culture vial }\end{array}$ & $\begin{array}{l}\text { Average shoot } \\
\text { length }(\mathrm{cm})\end{array}$ \\
\hline MS basal & & 5 & $19.6 \pm 1.01^{\mathrm{k}}$ & $1.8 \pm 0.74^{\text {ghi }}$ & $1.68 \pm 0.25^{\text {ef }}$ \\
\hline \multirow{6}{*}{$\mathrm{MS}+\mathrm{BAP}$} & 1.0 & 5 & $18.8 \pm 0.74^{\mathrm{jk}}$ & $2 \pm 0.63^{\text {fghi }}$ & $2.8 \pm 0.74^{\text {abcd }}$ \\
\hline & 1.5 & 5 & $17.8 \pm 1.16^{\mathrm{hi}}$ & $3 \pm 0.89^{\text {cdefg }}$ & $3.02 \pm 0.59^{\mathrm{abc}}$ \\
\hline & 2.0 & 5 & $16.6 \pm 1.01^{\mathrm{hi}}$ & $3.6 \pm 0.64^{\mathrm{bcd}}$ & $3.04 \pm 0.58^{\mathrm{abc}}$ \\
\hline & 2.5 & 5 & $15 \pm 1.41^{\mathrm{ef}}$ & $4.6 \pm 0.48^{\mathrm{ab}}$ & $3.44 \pm 0.37^{\mathrm{a}}$ \\
\hline & 3.0 & 5 & $18.4 \pm 1.01^{\mathrm{hi}}$ & $4.2 \pm 0.74^{\mathrm{abc}}$ & $3 \pm 0.89^{\mathrm{abc}}$ \\
\hline & 3.5 & 5 & $21 \pm 1.67^{1}$ & $3.4 \pm 0.48^{\text {cde }}$ & $2.2 \pm 0.37^{\text {bcde }}$ \\
\hline \multirow{6}{*}{ MS + Kinetin } & 1.0 & 5 & $15 \pm 1.41^{\mathrm{fg}}$ & $1.2 \pm 0.74^{i}$ & $0.84 \pm 0.18^{f}$ \\
\hline & 1.5 & 5 & $13.8 \pm 1.46^{\mathrm{ef}}$ & $2.0 \pm 0.63^{\mathrm{fghi}}$ & $1.1 \pm 0.74^{\mathrm{ef}}$ \\
\hline & 2.0 & 5 & $12 \pm 0.89^{\mathrm{ef}}$ & $2.8 \pm 0.74^{\mathrm{defgh}}$ & $1.2 \pm 0.4^{\mathrm{ef}}$ \\
\hline & 2.5 & 5 & $9.6 \pm 1.01^{\mathrm{b}}$ & $3.0 \pm 0.89^{\text {cdefg }}$ & $2.8 \pm 0.74^{\text {abcd }}$ \\
\hline & 3.0 & 5 & $8.2 \pm 1.16^{a}$ & $4.8 \pm 0.89^{a}$ & $3.4 \pm 0.48^{a}$ \\
\hline & 3.5 & 5 & $11.8 \pm 1.32^{\text {cde }}$ & $3.4 \pm 0.48^{\text {cde }}$ & $2.2 \pm 0.74^{\text {bcde }}$ \\
\hline \multirow{4}{*}{$\mathrm{MS}+\mathrm{BAP}+$ kin } & $0.5+0.5$ & 5 & $14.6 \pm 1.62^{\mathrm{ef}}$ & $1.8 \pm 0.74^{\text {ghi }}$ & $1.1 \pm 0.74^{\text {ef }}$ \\
\hline & $1.0+0.5$ & 5 & $12.2 \pm 0.74^{\mathrm{ef}}$ & $2.0 \pm 0.63^{\mathrm{fghi}}$ & $1.84 \pm 0.54^{\text {def }}$ \\
\hline & $1.5+0.5$ & 5 & $9.8 \pm 1.72^{\mathrm{bcd}}$ & $3.6 \pm 0.8^{\mathrm{bcd}}$ & $2.8 \pm 0.74^{\text {abcd }}$ \\
\hline & $2.0+0.5$ & 5 & $11.8 \pm 1.32^{\mathrm{def}}$ & $3.0 \pm 0.89^{\text {cdefg }}$ & $2.2 \pm 0.74^{\text {bcde }}$ \\
\hline \multirow{5}{*}{$\mathrm{MS}+\mathrm{BAP}+\mathrm{NAA}$} & $0.5+0.5$ & 5 & $19 \pm 0.89^{j \mathrm{k}}$ & $1.6 \pm 0.48^{\mathrm{hi}}$ & $1.6 \pm 0.8^{\text {ef }}$ \\
\hline & $1.0+0.5$ & 5 & $18.4 \pm 1.01 \mathrm{hi}$ & $2.0 \pm 0.63^{\text {fghi }}$ & $2.8 \pm 0.74^{\text {abcd }}$ \\
\hline & $1.5+0.5$ & 5 & $15 \pm 1.41^{\mathrm{gh}}$ & $2.2 \pm 0.74^{\text {efghi }}$ & $3 \pm 0.89^{\mathrm{abc}}$ \\
\hline & $2.0+0.5$ & 5 & $9.6 \pm 1.01^{\mathrm{bc}}$ & $4.0 \pm 0.89^{\mathrm{abcd}}$ & $3.4 \pm 0.48^{a}$ \\
\hline & $2.5+0.5$ & 5 & $11.8 \pm 1.32^{\text {def }}$ & $3.2 \pm 0.74^{\text {cdef }}$ & $3.02 \pm 0.59^{\mathrm{abc}}$ \\
\hline \multirow{5}{*}{$\mathrm{MS}+\mathrm{Kin}+\mathrm{NAA}$} & $1.0+0.5$ & 5 & $25 \pm 0.89^{1}$ & $1.0 \pm 0.89^{i}$ & $0.76 \pm 0.20^{f}$ \\
\hline & $2.0+0.5$ & 5 & $22 \pm 0.89^{1}$ & $1.6 \pm 0.8^{\mathrm{hi}}$ & $1.59 \pm 0.37^{\mathrm{ef}}$ \\
\hline & $3.0+0.5$ & 5 & $19.6 \pm 1.01^{\mathrm{k}}$ & $2.8 \pm 0.74^{\text {defgh }}$ & $2.02 \pm 0.51^{\text {cde }}$ \\
\hline & $4.0+0.5$ & 5 & $15 \pm 1.41^{\text {gh }}$ & $3.4 \pm 0.48^{\text {cde }}$ & $3.44 \pm 0.37^{\mathrm{a}}$ \\
\hline & $5.0+0.5$ & 5 & $17.8 \pm 1.16^{\mathrm{hi}}$ & $3.0 \pm 0.63^{\text {cdefg }}$ & $3.04 \pm 0.83^{3 \mathrm{acc}}$ \\
\hline \multirow{6}{*}{$\mathrm{MS}+\mathrm{BAP}+\mathrm{Kin}+\mathrm{NAA}$} & $0.5+0.5+0.5$ & 5 & $22.4 \pm 1.74^{1}$ & $1.6 \pm 0.8^{\mathrm{hi}}$ & $1.8 \pm 0.74^{\text {def }}$ \\
\hline & $1.0+1.0+0.5$ & 5 & $20.2 \pm 1.32^{\mathrm{k}}$ & $2.8 \pm 0.74^{\mathrm{defgh}}$ & $2.14 \pm 0.36^{\text {bcde }}$ \\
\hline & $1.5+1.5+0.5$ & 5 & $18.8 \pm 0.74^{\mathrm{jk}}$ & $3.0 \pm 0.63^{\text {cdefg }}$ & $2.2 \pm 0.74^{\text {bcde }}$ \\
\hline & $2.0+2.0+0.5$ & 5 & $15 \pm 1.41^{\mathrm{fg}}$ & $3.2 \pm 0.74^{\text {cdef }}$ & $3.6 \pm 0.8^{\mathrm{a}}$ \\
\hline & $2.5+2.5+0.5$ & 5 & $17.8 \pm 1.16^{\mathrm{hi}}$ & $2.0 \pm 0.67^{\text {fghi }}$ & $3.2 \pm 0.74^{\mathrm{ab}}$ \\
\hline & LSD0.05 & & 1.73 & 1.02 & 0.91 \\
\hline
\end{tabular}

BAP after 12 days of inoculation while best shoot initiation response $(80 \%)$ from twin scales was obtained at high concentration of BAP i.e. $4.5 \mathrm{mg} / \mathrm{L}$ of BAP after 15 days of inoculation. Sen and Sharma ${ }^{9}$ achieved best shoot induction response within 20-25 days of culture from shoot tip explants obtained from 30 days old aseptically germinated seedlings of Coleus forskohlii, using $2.0 \mathrm{mg} / \mathrm{L}$ of BA. The use of meristem for tissue culture allows rapid clonal multiplication and virus elimination for the study of shoots and root development in vitro ${ }^{10}$. When MS medium was supplemented with different concentrations of Kinetin, $80 \%$ shoot initiation response was obtained from twin scale at $3.0 \mathrm{mg} / \mathrm{L}$ of kinetin after 9 days of inoculation. Tadhani et al. ${ }^{11}$, reported that $4.0 \mathrm{mg} / \mathrm{L}$ of kinetin showed maximum shoot formation response. Nuutila et al., ${ }^{12}$ and Ali and Afghan ${ }^{13}$ reported that cultivation of same species may differ drastically in their requirement for essential medium components.

Combination of BAP with Kinetin also showed good results for shoot initiation from twin scales. Among different combinations $1.5 \mathrm{mg} / \mathrm{L}$ BAP $+0.5 \mathrm{mg} / \mathrm{L}$ Kinetin showed $88 \%$ shoot initiation response after 12.2 days of twin scale inoculation while at the same concentration $80 \%$ shoot formation response was obtained after 13.8 days of meristem inoculation. Promotive effect of the combination of BAP with Kinetin for in vitro shoot formation have also been reported by Stanilova ${ }^{14}$. According to him murashige and skoog (MS) medium +1.0 $\mathrm{mg} / \mathrm{L} \mathrm{BAP}+1.0 \mathrm{mg} / \mathrm{L}$ kinetin was flavourable for direct organogenesis from bulb, stem, leaves and ovaries explants. Smitha et al. ${ }^{15}$ reported similar findings for the enhanced production of dark green healthy shoot when a combination of BAP with Kinetin was used in MS medium.

6-Benzylamino purine (BAP) was also used in combination with NAA for efficient shoot formation and initiation response. When BAP was used with NAA, $2 \mathrm{mg} / \mathrm{L} \mathrm{BAP}+0.5 \mathrm{mg} / \mathrm{L}$ NAA gave optimum results from both meristematic and twin scales explants with $84 \%$ and $88 \%$ shoot formation response after 10 and 12 days of inoculation with average shoot length of 3.0 and $3.44 \mathrm{~cm}$ respectively. Statistically it can be further analyzed that shoot formation response occurred at low concentration of BAP + Kinetin while shoot initiation from twin scales was obtained at high concentration of BAP + Kinetin. The best results obtained at $2 \mathrm{mg} / \mathrm{L} \mathrm{BAP}+0.5 \mathrm{mg} / \mathrm{L}$ Kinetin for shoot formation and initiation from both kinds of explants (twin scales and meristem) and are very much close to results obtained at $1.5 \mathrm{mg} / \mathrm{L} \mathrm{BAP}+0.5 \mathrm{mg} / \mathrm{L}$ NAA.

It is suggested from above mentioned results that MS medium supplemented with $2 \mathrm{mg} / \mathrm{L} \mathrm{BAP}+0.5 \mathrm{mg} / \mathrm{L} \mathrm{NAA}$ proved best for shoot initiation as well as shoot formation. 
TABLE-3

EFFECT OF DIFFERENT CONCENTRATIONS AND COMBINATIONS OF AUXINS FOR in vitro ROOTING

\begin{tabular}{|c|c|c|c|c|c|}
\hline Media & $\begin{array}{c}\text { Composition } \\
(\mathrm{mg} / \mathrm{L})\end{array}$ & $\begin{array}{l}\text { No. of test tubes } \\
\text { cultured }\end{array}$ & $\begin{array}{l}\text { Days for root } \\
\text { formation }\end{array}$ & $\begin{array}{c}\text { Average no. } \\
\text { of roots }\end{array}$ & $\begin{array}{c}\text { Average root } \\
\text { length }\end{array}$ \\
\hline MS medium & & 5 & $23.8 \pm 0.74^{\mathrm{k}}$ & $0.6 \pm 0.89^{i}$ & $0.28 \pm 0.11^{\mathrm{f}}$ \\
\hline $1 / 2 \mathrm{MS}+\mathrm{NAA}$ & 0.5 & 5 & $19 \pm 0.89^{\mathrm{jk}}$ & $1.6 \pm 0.89^{\mathrm{hi}}$ & $0.82 \pm 0.57^{\text {def }}$ \\
\hline $1 / 2 \mathrm{MS}+\mathrm{NAA}$ & 1.0 & 5 & $15 \pm 1.41^{\text {efgh }}$ & $2.2 \pm 0.74^{\mathrm{fgh}}$ & $1.14 \pm 0.50^{\text {abcde }}$ \\
\hline $1 / 2 \mathbf{M S}+\mathbf{N A A}$ & 1.5 & 5 & $12.2 \pm 0.74^{b c}$ & $4 \pm 0.89^{\mathrm{abc}}$ & $1.56 \pm 0.36^{\mathrm{abc}}$ \\
\hline $1 / 2 \mathrm{MS}+\mathrm{NAA}$ & 2.0 & 5 & $14.4 \pm 1.85 \mathrm{~d}^{\mathrm{efg}}$ & $3 \pm 0.89 b^{\text {cdefg }}$ & $1.36 \pm 0.57^{\text {abcde }}$ \\
\hline NAA & 0.5 & 5 & $17.6 \pm 0.8^{\text {hijk }}$ & $2 \pm 0.89^{\mathrm{fgh}}$ & $0.74 \pm 0.28^{\text {ef }}$ \\
\hline NAA & 1.0 & 5 & $16.4 \pm 1.2^{\text {ghij }}$ & $3.2 \pm 0.74^{\text {bcdef }}$ & $0.82 \pm 0.57^{\text {def }}$ \\
\hline NAA & 1.5 & 5 & $11.8 \pm 1.32^{a}$ & $5.2 \pm 0.74^{\mathrm{a}}$ & $1.76 \pm 0.38^{a}$ \\
\hline NAA & 2.0 & 5 & $13.8 \pm 1.46 \mathrm{~b}^{\mathrm{cd}}$ & $4 \pm 0.89^{\mathrm{abc}}$ & $1.12 \pm 0.31^{\mathrm{abcde}}$ \\
\hline $1 / 2 \mathrm{MS}+\mathrm{IBA}$ & 0.5 & 5 & $15 \pm 1.41^{\mathrm{fgh}}$ & $3.2 \pm 0.74^{\text {bcdef }}$ & $0.96 \pm 0.42^{\text {cde }}$ \\
\hline $1 / 2 \mathrm{MS}+\mathrm{IBA}$ & 1.0 & 5 & $16.4 \pm 1.2^{\mathrm{ghi}}$ & $3.8 \pm 0.95^{\mathrm{bcd}}$ & $1.0 \pm 0.24^{\text {bcde }}$ \\
\hline $1 / 2 \mathbf{M S}+\mathbf{I B A}$ & 1.5 & 5 & $12 \pm 0.89^{b c}$ & $4.4 \pm 0.8^{\text {abc }}$ & $1.36 \pm 0.57^{\text {abcde }}$ \\
\hline $1 / 2 \mathrm{MS}+\mathrm{IBA}$ & 2.0 & 5 & $14 \pm 0.74^{\text {cdef }}$ & $3.8 \pm 0.74^{\mathrm{bcd}}$ & $1.14 \pm 0.50^{\text {abcde }}$ \\
\hline IBA & 0.5 & 5 & $17.6 \pm 0.8^{\mathrm{ijk}}$ & $2.0 \pm 0.89^{\text {fgh }}$ & $0.28 \pm 0.11^{\mathrm{f}}$ \\
\hline IBA & 1.0 & 5 & $14.4 \pm 1.85 \mathrm{~d}^{\mathrm{efg}}$ & $3.2 \pm 0.74^{\text {bcdef }}$ & $0.82 \pm 0.57^{\mathrm{def}}$ \\
\hline IBA & 1.5 & 5 & $11.8 \pm 1.32^{b}$ & $4 \pm 0.89^{\mathrm{abc}}$ & $1.2 \pm 0.4^{\text {abcde }}$ \\
\hline IBA & 2.0 & 5 & $13.8 \pm 1.46 \mathrm{~b}^{\mathrm{cd}}$ & $3.6 \pm 0.48^{\text {bcde }}$ & $1.12 \pm 0.11^{\text {abcde }}$ \\
\hline $1 / 2 \mathrm{MS}+\mathrm{NAA}+\mathrm{IBA}$ & $0.5+0.5$ & 5 & $15.2 \pm 1.16^{\mathrm{ggh}}$ & $2 \pm 0.63^{\mathrm{fgh}}$ & $1.22 \pm 0.08^{\text {abcde }}$ \\
\hline $1 / 2 \mathrm{MS}+\mathrm{NAA}+\mathrm{IBA}$ & $1.0+0.5$ & 5 & $14.8 \pm 1.16^{\mathrm{dfgh}}$ & $2.4 \pm 0.22^{\text {efgh }}$ & $1.4 \pm 0.08^{\mathrm{abcde}}$ \\
\hline $1 / 2 \mathrm{MS}+\mathrm{NAA}+\mathrm{IBA}$ & $1.5+0.5$ & 5 & $14.0 \pm 0.75^{\mathrm{cdef}}$ & $3.2 \pm 0.52^{\text {bcdef }}$ & $1.5 \pm 0.06^{\mathrm{abcd}}$ \\
\hline $1 / 2 \mathrm{MS}+\mathrm{NAA}+\mathrm{IBA}$ & $2.0+0.5$ & 5 & $13.0 \pm 0.89^{\mathrm{bc}}$ & $3.6 \pm 0.4^{\text {bcde }}$ & $1.68 \pm 0.12^{\mathrm{abc}}$ \\
\hline $\mathrm{NAA}+\mathrm{IBA}$ & $0.5+0.5$ & 5 & $18.2 \pm 1.6^{\mathrm{jk}}$ & $1.8 \pm 0.34^{\mathrm{gh}}$ & $1.28 \pm 0.10^{\text {abcde }}$ \\
\hline $\mathrm{NAA}+\mathrm{IBA}$ & $1.0+0.5$ & 5 & $17.0 \pm 1.0^{\text {ghijk }}$ & $2.2 \pm 0.34^{\mathrm{fgh}}$ & $1.46 \pm 0.10^{\text {abcde }}$ \\
\hline NAA + IBA & $1.5+0.5$ & 5 & $15.4 \pm 1.2^{\mathrm{fgh}}$ & $2.8 \pm 0.34^{\text {cdefgh }}$ & $1.7 \pm \mathbf{0 . 0 8}^{\mathrm{ab}}$ \\
\hline \multirow[t]{2}{*}{$\mathrm{NAA}+\mathrm{IBA}$} & $2.0+0.5$ & 5 & $17.2 \pm 1.32^{\text {ghijk }}$ & $2.6 \pm 0.36^{\text {defgh }}$ & $1.48 \pm 0.07^{\mathrm{abcd}}$ \\
\hline & LSD0.05 & & 1.76 & 1.08 & 0.58 \\
\hline
\end{tabular}

In vitro shoot multiplication: Well developed in vitro shoots were shifted on MS medium supplemented with varying concentration of cytokinins either alone or in combination with each other and with auxins for efficient shoot multiplication.

It was observed that MS medium containing $2.5 \mathrm{mg} / \mathrm{L}$ of BAP proved best i.e. an average of 4.6 shoots per culture vial were formed after 15 days of inoculation with average shoot length of $3.44 \mathrm{~cm}$ (Table-2). By further increasing the concentration of BAP shoot multiplication response was decreased. Oo et al., ${ }^{16}$ reported best shoot multiplication response after 4 weeks of inoculation on MS medium containing $3 \mathrm{mg} / \mathrm{L}$ of BAP while in present investigation multiplication response was obtained at low concentration i.e. at $2.5 \mathrm{mg} / \mathrm{L}$ of BAP and in less span of time. Escuitia et al., ${ }^{17}$ reported that best medium composition for in vitro shoot multiplication of $T$. pavonia belonging to family Liliaceae was $4.5 \mu \mathrm{M}$ 2,4-D with $2.2 \mu \mathrm{M}$ BAP in medium containing $1.0 \mathrm{~g} / \mathrm{L}$ of activated charcoal and resulted in four shoots per plant. According to him 48 plants can be produced from one bulb after 5 months of culture inoculation. But in present study combination of 2,4-D with BAP did not show any promotive results for in vitro shoot multiplication (results not shown in table). According to Yew et al. ${ }^{18}$ relatively high concentrations of cytokinins should be present to observe high multiplication rates. When MS medium was supplemented with kinetin, best shoot multiplication response was obtained at $3.0 \mathrm{mg} / \mathrm{L}$ of Kinetin i.e. 4.8 shoots per culture were formed after 8 days of inoculation with average shoot length of $3.4 \mathrm{~cm}$.

Statistics of Table-2 shows that the results obtained at $4 \mathrm{mg} / \mathrm{L} \mathrm{Kin.}+0.5 \mathrm{mg} / \mathrm{L} \mathrm{NAA}$ are near to results obtained at $2 \mathrm{mg} / \mathrm{L} \mathrm{BAP}+2.0 \mathrm{mg} / \mathrm{L} \mathrm{kin}+0.5 \mathrm{mg} / \mathrm{L} \mathrm{NAA}$. Statistical analysis of Table- 2 further gives an account that uniform shoot multiplication response was obtained by using the combinations of BAP + Kin., BAP + NAA, Kin + NAA and BAP + Kin + NAA. However, Kunchanapoom et al. ${ }^{19}$ reported best results at $3 \mathrm{mg} / \mathrm{L} \mathrm{BAP}+1.0 \mathrm{mg} / \mathrm{L}$ Kinetin while best results in present investigation were obtained at low concentration of hormones.

In conclusion for in vitro shoot multiplication, MS medium supplemented with $3 \mathrm{mg} / \mathrm{L}$ of kinetin proved best for in vitro shoot multiplication because at this concentration maximum i.e. 4.8 shoots per culture vial were obtained within 8.2 days of inoculation with an average shoot length of 3.4 $\mathrm{cm}$.

In vitro rooting: Well developed in vitro shoots when attained considerable size i.e. 4-5 cm were shifted on MS medium provided by different concentration and combination of different auxins i.e. NAA and IBA either alone or in combination with each other. Data presented in Table-3 shows that when half and full strength MS medium was supplemented with varying concentrations of NAA, optimum in vitro rooting response was obtained at $1.5 \mathrm{mg} / \mathrm{L}$ of NAA. At this concentration an average of 5.2 roots/plant were formed after 11.8 days of inoculation with an average root length of $1.76 \mathrm{~cm}$. Khan et al. ${ }^{20}$ reported best results at $2 \mathrm{mg} / \mathrm{L}$ of IBA i.e. 5.84 roots with an average root length of $0.5 \mathrm{~cm}$. Although in present study also when IBA was used in half and full strength MS medium good rooting response was obtained but NAA performed better than IBA (Table-3). Half and full strength MS medium was also supplemented with different combinations of NAA and IBA but it also failed to show good results than NAA alone. 
TABLE-4

HARDENING OF WELL DEVELOPED in vitro PLANTS

\begin{tabular}{clcccc}
\hline S. No. & Media & No of plants shifted & Days of hardening & No of plants hardened & $\%$ age of hardened plants \\
\hline 1 & Sand & 10 & $22.5 \pm 0.92^{\mathrm{b}}$ & $5.9 \pm 0.55^{\mathrm{b}}$ & 59 \\
2 & Silt & 10 & $24.9 \pm 1.17^{\mathrm{a}}$ & $3.1 \pm 0.63^{\mathrm{c}}$ & 31 \\
3 & Peat & $\mathbf{1 0}$ & $\mathbf{1 8 . 2} \pm \mathbf{0 . 5 3}^{\mathbf{c}}$ & $\mathbf{1 0 . 0} \pm \mathbf{0 . 7 7}^{\mathrm{a}}$ & $\mathbf{1 0 0}$ \\
4 & Sand + Peat & 10 & $18.9 \pm 0.62^{\mathrm{c}}$ & $9.9 \pm 0.83^{\mathrm{a}}$ & 99 \\
5 & Sand + Peat +Silt & 10 & $21.2 \pm 1.26^{\mathrm{b}}$ & $8.2 \pm 0.64^{\mathrm{a}}$ & 82 \\
\hline LSD 0.05 & - & 2.05 & 1.86 & - \\
\hline \multicolumn{7}{l}{ Means followed by different letters in the same column differ significantly at $\mathrm{p}=0.05$ according to Duncan's new multiple range tests }
\end{tabular}

TABLE-5

EFFECT OF DIFFERENT CONCENTRATION OF 2, 4-D AND NAA WITH BAP ON in vitro CALLUS INDUCTION

\begin{tabular}{|c|c|c|c|c|c|c|c|c|}
\hline \multirow[t]{2}{*}{ Media } & \multirow{2}{*}{$\begin{array}{l}\text { Composition } \\
\quad(\mathrm{mg} / \mathrm{L})\end{array}$} & \multirow{2}{*}{$\begin{array}{l}\text { No. of test } \\
\text { tube } \\
\text { inoculated }\end{array}$} & \multicolumn{2}{|c|}{$\begin{array}{l}\text { No. of test tube showing } \\
\text { callus induction }\end{array}$} & \multicolumn{2}{|c|}{$\begin{array}{l}\text { Days for callus } \\
\text { induction }\end{array}$} & \multicolumn{2}{|c|}{$\begin{array}{l}\text { Rate of callus } \\
\text { induction }(\%)\end{array}$} \\
\hline & & & T.S. & $\mathrm{M}$ & T.S. & $\mathrm{M}$ & T.S. & $\mathrm{M}$ \\
\hline Basal & & 5 & $0 \pm 0^{c}$ & $0 \pm 0^{\mathrm{d}}$ & $0 \pm 0^{\mathrm{a}}$ & $0 \pm 0^{\mathrm{a}}$ & 0 & 0 \\
\hline \multirow{4}{*}{$\mathrm{MS}+2,4-\mathrm{D}$} & 1.0 & 5 & $1.8 \pm 0.74^{b}$ & $1 \pm 0.63^{c}$ & $14.6 \pm 0.48^{c}$ & $16 \pm 0.89^{d}$ & 36 & 20 \\
\hline & 2.0 & 5 & $3 \pm 0.89^{\mathrm{b}}$ & $3.8 \pm 0.74^{\mathrm{bc}}$ & $12.8 \pm 0.74^{\mathrm{ab}}$ & $15.4 \pm 1.35^{\mathrm{b}}$ & 60 & 68 \\
\hline & 3.0 & 5 & $3.2 \pm 0.74^{\mathrm{a}}$ & $3 \pm \mathbf{0 . 6 3}^{\mathrm{a}}$ & $12.6 \pm 1.01^{a}$ & $13.2 \pm 0.74^{\mathrm{a}}$ & 64 & 60 \\
\hline & 4.0 & 5 & $2.8 \pm 0.74^{\mathrm{ab}}$ & $2.6 \pm 0.48^{\mathrm{ab}}$ & $13.8 \pm 0.74^{\mathrm{ab}}$ & $14.6 \pm 0.48^{b}$ & 56 & 52 \\
\hline \multirow{5}{*}{$\mathrm{MS}+\mathrm{NAA}+\mathrm{BAP}$} & $1.0+0.25$ & 5 & $2 \pm 0.89^{b}$ & $1.8 \pm 0.74 \mathrm{~b}^{\mathrm{c}}$ & $13.8 \pm 0.74^{\mathrm{ab}}$ & $14.6 \pm 0.48^{\mathrm{ab}}$ & 40 & 36 \\
\hline & $2.0+0.25$ & 5 & $4 \pm 0.48^{a}$ & $3.4 \pm 0.89^{\mathrm{abc}}$ & $9.8 \pm 1.72^{\mathrm{a}}$ & $11.8 \pm 0.74^{\text {ab }}$ & 80 & 68 \\
\hline & $1.0+0.5$ & 5 & $2.6 \pm 0.48^{\mathrm{ab}}$ & $3 \pm 0.63^{\mathrm{a}}$ & $14.6 \pm 1.62^{c}$ & $13.8 \pm 1.32^{\mathrm{a}}$ & 52 & 60 \\
\hline & $2.0+0.5$ & 5 & $1.8 \pm 0.74^{\mathrm{b}}$ & $1.0 \pm 0.63^{\mathrm{c}}$ & $15 \pm 1.41^{\mathrm{d}}$ & $16 \pm 1.41^{\mathrm{c}}$ & 36 & 10 \\
\hline & CSD 0.05 & - & 0.99 & 0.95 & 1.55 & 1.35 & - & - \\
\hline
\end{tabular}

Means followed by different letters in the same column differ significantly at $\mathrm{p}=0.05$ according to Duncan's new multiple range tests. T.S. $=$ Twin scales; $\mathrm{M}=$ Meristem

In conclusion full strength MS medium containing 1.5 $\mathrm{mg} / \mathrm{L}$ of NAA was proved to be best for in vitro rooting because at this concentration maximum roots (5.2) were formed after 11 days of inoculation with an average root length of $1.76 \mathrm{~cm}$.

In vitro harding: In vitro generated plants were shifted to pots containing different combinations of silt, sand and peat either alone or in combination with each other. Plants showed different responses towards different soil types. In case of sand, $59 \%$ hardening response was obtained in 22.5 days after shifting. In case of silt $31 \%$ hardening response in 24.9 days after rooting was obtained. In case of soil mixture i.e., pots containing soil mixture of sand + peat + silt $(1: 1: 1), 82 \%$ hardening response was obtained. The best results were obtained in case of peat i.e., $100 \%$ hardening response was obtained after 18.2 days while $99 \%$ hardening response was obtained after 18.9 days in case of sand + peat (1:1) (Table-4). Ali et al., ${ }^{13}$ reported best hardening response of Mentha arvensis in a mixture of sand + soil + peat at 1:1:1 but in our study this mixture produced only $79.2 \%$ hardening response. This difference may be due to the difference in the humidity requirement of the plants.

Callogenesis: In tissue culture studies the formation of callus is a prerequisite for organogenesis. The callus formation is followed by dramatic changes in the appearance and metabolism of cells ${ }^{21}$. The experimental result regarding callus induction and growth showed that the callus formation varies with type of explants and also the media composition. This is due to the fact that plant genes are not only involved in plant growth and development they also govern the inheritance of callus growth $^{22}$. Among all the treatments used in present study, highest callus induction response was obtained at $3 \mathrm{mg} / \mathrm{L}$ of
2,4-D. Naik et al., ${ }^{23}$ used $2 \mathrm{mg} / \mathrm{L}$ of 2,4-D in bulbous plant Ornithogalum virens to obtain callus induction up to $75 \%$ in greater span of time i.e. 2-3 weeks. When BAP was used in combination with NAA, a wide variation occurred in days to callus initiation and percentage of callus formation from different explants. According to Tillman et al. ${ }^{24}$ specific binding sites for both auxin and cytokinin reside within the cells. Andre and Shererr ${ }^{25}$ reported that this binding of auxin and cytokinin with cells triggers the expression of enzyme which results in cell division. The best response in combination of BAP and NAA was shown by twin scale explants in medium containing $2.0 \mathrm{mg} / \mathrm{L}$ of NAA and $0.25 \mathrm{mg} / \mathrm{L}$ of BAP with $80 \%$ response after 5 week of inoculation (Table-5).

Morphogenic callus of Lilium was cultured on MS medium with or without growth regulators either alone or in combination with each other. The data presented in Table-6 shows that when callus was cultured on MS basal medium only $24 \%$ shoot formation response was obtained. The callus subjected to hormone free medium may contain a population of cells which were the part of original meristematic tissues. Meristematic cells of callus retain relatively higher totipotency and swiftly induce the organ formation even on the basal medium $^{26}$. Part of nodular and smooth callus, which did not differentiate in hormone free medium, when shifted in to the medium supplemented cytokinins, underwent organogenesis. When MS medium was supplemented with different growth regulators, shoot formation response was enhanced and best results were obtained on $\mathrm{M}_{3}$ medium i.e. MS medium containing $1.5 \mathrm{mg} / \mathrm{L} \mathrm{BAP}$. At this concentration $84 \%$ shoot regeneration response was obtained (Table-6). Our findings are also in accordance with the results of Mori et al. ${ }^{27}$ who reported $80 \%$ regeneration frequency in 20 genotypes on MS medium 
TABLE-6

ORGANOGENESIS FROM MORPHOGENIC CALLUS IN Lillium

\begin{tabular}{|c|c|c|c|c|c|c|}
\hline Code & Media (MS) & $\begin{array}{l}\text { Concentration } \\
(\mathrm{mg} / \mathrm{L})\end{array}$ & $\begin{array}{c}\text { Number of } \\
\text { cultures examined }\end{array}$ & $\begin{array}{l}\text { Age of cultures } \\
\text { (week) }\end{array}$ & $\begin{array}{l}\text { Number of test tubes showing } \\
\text { shoot induction }\end{array}$ & $\begin{array}{c}\text { Rate of regeneration } \\
\text { (\% age })\end{array}$ \\
\hline $\mathrm{M}_{1}$ & MS Basal & & 5 & 11 & $1.2 \pm 0.4^{\mathrm{g}}$ & 24 \\
\hline $\mathrm{M}_{2}$ & \multirow{4}{*}{ BAP } & 1.0 & 5 & 11 & $2.0 \pm 0.63^{\text {defg }}$ & 40 \\
\hline $\mathrm{M}_{3}$ & & 1.5 & 5 & 11 & $4.2 \pm 0.75^{\mathrm{a}}$ & 84 \\
\hline $\mathrm{M}_{4}$ & & 2.0 & 5 & 11 & $3.0 \pm 0.63^{\mathrm{bc}}$ & 60 \\
\hline $\mathrm{M}_{5}$ & & 2.5 & 5 & 11 & $2.2 \pm 0.75^{\text {dcef }}$ & 44 \\
\hline $\mathrm{M}_{6}$ & \multirow{3}{*}{ Kinetin } & 1.0 & 5 & 11 & $1.2 \pm 0.4^{\mathrm{g}}$ & 24 \\
\hline $\mathrm{M}_{8}$ & & 2.0 & 5 & 11 & $2.4 \pm 0.4^{\mathrm{cde}}$ & 48 \\
\hline $\mathrm{M}_{9}$ & & 2.5 & 5 & 11 & $1.2 \pm 0.40^{\mathrm{g}}$ & 24 \\
\hline $\mathrm{M}_{10}$ & \multirow{4}{*}{$\mathrm{BAP}+$ Kinetin } & $0.25+0.25$ & 5 & 11 & $1.6 \pm 0.49^{\text {efg }}$ & 32 \\
\hline $\mathrm{M}_{11}$ & & $0.5+0.25$ & 5 & 11 & $1.8 \pm 0.76^{\text {defg }}$ & 36 \\
\hline $\mathrm{M}_{12}$ & & $1.0+0.50$ & 5 & 11 & $3.4 \pm 0.49^{\mathrm{ab}}$ & 68 \\
\hline $\mathrm{M}_{13}$ & & $2.0+0.50$ & 5 & 11 & $2.6 \pm 0.49^{\text {bcd }}$ & 52 \\
\hline $\mathrm{M}_{14}$ & \multirow{3}{*}{$2,4-\mathrm{D}$} & 1 & 5 & 11 & $1.2 \pm 0.4^{\mathrm{g}}$ & 24 \\
\hline $\mathrm{M}_{16}$ & & 3 & 5 & 11 & $1.4 \pm 0.49^{\mathrm{fg}}$ & 28 \\
\hline $\mathrm{M}_{17}$ & & 4 & 5 & 11 & $1.4 \pm 0.49^{\mathrm{fg}}$ & 28 \\
\hline LSD $(0$. & & & & & 0.803 & \\
\hline
\end{tabular}

supplemented with $22 \mu \mathrm{M}$ 6-benzyladenine (BA). Peros et al. ${ }^{28}$ also reported an increase in morphogenic response of callus after cytokinin treatment. Cytokinin plays a role in organogenesis by stimulating cell division both in vivo and in vitro. Immunocytochemistry and direct measurement of cytokinin both reveal high cytokinin levels in mitotically active areas, such as the root and shoot meristems and very low levels are found in tissues where the cell cycle is arrested ${ }^{29,30}$. Application of exogenous cytokinin to some organs that normally lack this hormone has been shown to induce cell division ${ }^{31}$. The ability of cytokinins to initiate shoots from callus in tissue culture and the initiation of ectopic meristems in cytokinin overproducing plants suggest a role for cytokinins in SAM (Shoot apical meristem) development.

As for as combination of BAP with Kinetin in present investigation is concerned no good results for regeneration were obtained (Table-6). The best combination observed was $1.0 \mathrm{mg} / \mathrm{L} \mathrm{BAP}$ and $0.50 \mathrm{mg} / \mathrm{L}$ Kinetin where only $68 \%$ regeneration response was obtained. The difference in results may be due to the variation in salts concentration and cultural conditions.

\section{REFERENCES}

1. S. Kumar, D.R. Sharma, Y.D. Sharma and N.S. Pathania, Horticult. Sci., 34, 77 (2007).

2. D.T. Beatties and J.W. White, in eds: A.A. De Hertogh and M. Le Nard, Lilium Hybrids and Species. Physiology of Flower Bulbs. Amsterdam, London, New York, Elsevier: pp. 423-454 (1993).

3. J.P. Munafo Jr. and T.J. Gianfagna, J. Agric. Food Chem., 59, 5945 (2011).

4. B.S. Dilta, O.P. Sehgal, N.S. Pathania and S. Chander, J. Ornamental Horticult., 3, 67 (2000).

5. S. Kumar, D.R. Sharma, Y.D. Sharma and N.S. Pathania, Indian J. Agricult. Sci., 71, 463 (2001).

6. K.S. Gill and K.J.H.L. Arumuganathan, Theor. Appel. Genet., 98, 1248 (1999).

7. T. Murashige and F. Skoog, Physiol. Plant, 15, 473 (1962).

8. R.G.D. Steel and J.H. Torrie, Principles and Procedures of Statistics, 2nd edition. McGraw Hill Book Co. Inc., New York: pp. 232-249. (1980).
9. J. Sen and A.K. Sharma, Plant Cell Rep., 10, 666 (1991).

10. N. Altaf, M. Salih and S.H.M. Naqvi, Present Status of Tissue Culture Study in Lentil (Lens culinaris) Medik. Advance in Plant Tissue Culture, Proceedings of the 3rd National Meeting of Plant Tissue Culture Pakistan, pp 75-82 (1993).

11. M.B. Tadhani, V.H. Patel and R. Subhash, J. Food Compos. Anal., 20, 223 (2006).

12. A.M. Nuutila, C. Villiger and K.M. Oksman-Caldentey, Plant Cell Rep., 20, 1156 (2002).

13. K. Ali and S. Afghan, Pak. Sugar J., 18, 33 (2003).

14. M.I. Stanilova, V.P. Ilcheva and N.A. Zagorska, Plant Cell Rep., 13, 451 (1994).

15. P.S. Smitha, P.A. Nazeem, J. Thomas, R. Keshavachandran and D. Girija, J. Med. Aromt. Plant Sci., 27, 247 (2005).

16. T.K. Oo, AA. Khai and K.M. Lwin, Micropropagation of Rose (Hybrid Rosa spp.) by in vitro Culture Technique. GMSARN International Conference on Sustainable Development: Issues and Prospects for the GMS. pp. 1-2 (2008).

17. J.L.P. Escutia, L.M.V. García and A.M.A. Fernandez, Electr. J. Biotechnol., 13, 336 (2009).

18. C.K. Yew, B. Balakrishnan, J. Sundasekaran and S. Subramaniam, J. Med. Plant Res., 4, 2641 (2010).

19. K. Kunchanapoom, N. Posayapisit and K. Kunchanapoom, Not. Bot. Hort. Agrobot. Cluj., 37, 261 (2009).

20. S. Khan, N. Sheeba, R. Mariami, K. Naheed, N. Asma and S. Bushra, Pak. J. Bot., 42, 1103 (2010).

21. P.A. Aitchison, A.J. Macleod and M.M. Yeoman, Plant Tiss. Cell Cult., pp. 267-306 (1978).

22. H. Turhan, Afr. J. Biotechnol., 3, 375 (2004).

23. P.K. Naik and S. Nayak, Sci. Asia, 31, 409 (2005).

24. U. Tillman, G. Viola, B. Kaeyser, G.T. Siemerster, K. Palme, M. Lober and D. Klambt, EMBO. J., 8, 2463 (1989).

25. B. Andre and G.F.E. Shere, Planta, 185, 209 (1991).

26. F.A. Siddiqui, Ph. D. Thesis, A Study of the Elimination of Sugarcane Mosaic Virus from Saccharum officinarum by Means of in vitro Meristem and Callus culture and Some Biochemical aspects of regenerated healthy and infected plants. Department of Botany, University of Punjab, Lahore, Pakistan (1993).

27. S. Mori, Y. Adachi, S. Horimoto, S. Suzuki and M. Nakano, In Vitro Cell. Dev. Biol. Plant, 41, 783 (2005).

28. J.P. Peros, E. Bonnel and B. Reynaud, Plant Cell, Tiss. Org. Cult., 23, 145 (1990).

29. L. Corbesier, E. Prinsen, A. Jacqmard, P. Lejeune, H. Van Onckelen, C. Périlleux and G. Bernier, J. Exp. Bot., 54, 2511 (2003).

30. A.M. Rashotte, H.S. Chae, B.B. Maxwell and J.J. Kieber, Physiol. Plantarum, 123, 184 (2005).

31. D.I.B. Agostino and J.K. Joseph, Curr. Opin. Plant Biol., 2, 359 (1999). 